\title{
IMPLEMENTASI DISIPLIN GURU SD DALAM MENTAATI PERATURAN DISIPLIN
}

\author{
Iman Teguh \\ Pegawai Negeri Sipil Pemalang \\ Imanteguh5153@gmail.com
}

\begin{abstract}
This research methodology uses the approach of juridical sociology with descriptive of research type. The method of collecting data uses observation and interview. The method of analyze data uses qualitative description. The results of the research are: 1) the implementation of elementary school teacher's discipline to obey the roles of discipline state officer at UPPK Taman Dinas Pendidikan, Pemuda dan Olah raga in Pemalang regency, namely the application of the government role number 53 on 2010 about discipline state officer, and the role of Pemalang regent number 26 on 2012 about the day and work-time of the state officers at Pemalang regency. 2) The problem which the implementation of elementary school teacher's discipline to obey the roles of discipline state officer made is that not all the elementary school teachers obey the roles of discipline state officer about work-time of state officer. 3) The solution for solving the problem which the implementation of elementary school teacher's discipline to obey the roles of discipline state officer made namely: a) Specific socialization of the roles of discipline state officer and work time is needed. b) Intensive monitoring of the roles of discipline and work time for state officer should be done. c) The firm sanction for the elementary school teachers who break the roles of discipline state officer should be given. d) The day and the work time of the elementary teachers should be revised become flexible work time so that the teachers can do their duties without breaking the role of state officer discipline, especially on the role of the state officer work-time.
\end{abstract}

Keyword: Discipline, Elementary School Teacher, Work time;

\section{A. Pendahuluan}

Pendidikan adalah usaha sadar dan terencana untuk mewujudkan suasana belajar dan proses pembelajaran agar peserta didik secara aktif mengembangkan potensi dirinya untuk memiliki kekuatan spiritual keagamaan, pengendalian diri, kepribadian, kecerdasan, akhlak mulia, 
serta keterampilan yang diperlukan dirinya, masyarakat, bangsa dan Negara". ${ }^{1}$ Pendidikan nasional berfungsi mengembangkan kemampuan dan membentuk watak serta peradaban bangsa yang bermartabat dalam rangka mencerdaskan kehidupan bangsa, bertujuan untuk berkembangnya potensi peserta didik agar menjadi manusia yang beriman dan bertakwa kepada Tuhan Yang Maha Esa, berakhlak mulia, sehat, berilmu, cakap, kreatif, mandiri, dan menjadi warga negara yang demokratis serta bertanggung jawab. ${ }^{2}$ Untuk mencapai tujuan pendidikan nasional diperlukan pemenuhan hak atas pendidikan yang layak bagi seluruh warga negara Indonesia. Pendidikan merupakan hak asasi manusia (HAM) dan merupakan suatu sarana yang mutlak diperlukan untuk mewujudkan hak-hak yang lainnya.

Salah satu faktor yang sangat menentukan dalam mencapai tujuan pendidikan nasional adalah tersedianya guru yang profesional dalam menjalankan tugasnya, yakni guru yang bermental baik, berwibawa, berdaya guna dan berhasil guna, berkualitas tinggi, mempunyai kesadaran tinggi dan disiplin akan tanggung jawabnya sebagai seorang guru. PP RI No. 74 th. 2008 tentang Guru, pasal 1 ayat (1) menyebutkan bahwa: 3 "Guru adalah pendidik profesional dengan tugas utama mendidik, mengajar, membimbing, mengarahkan, melatih, menilai, dan mengevaluasi peserta didik pada pendidikan anak usia dini jalur pendidikan formal, pendidikan dasar, dan pendidikan menengah". Beban kerja Guru mencakup kegiatan pokok: merencanakan pembelajaran, melaksanakan pembelajaran, menilai hasil pembelajaran, membimbing dan melatih peserta didik; dan melaksanakan tugas tambahan yang melekat pada pelaksanaan

${ }^{1}$ UU Nomor 20 Tahun 2003 tentang Sistem Pendidikan Nasional, pasal 1 ayat (1)

${ }^{2}$ Ibid, Pasal 3

${ }^{3}$ Peraturan Pemerintah RI Nomor 74 tahun 2008 tentang Guru, pasal 1 ayat (1) 
kegiatan pokok sesuai dengan beban kerja Guru. ${ }^{4}$ Yang dimaksud dengan "tugas tambahan", misalnya menjadi pembina pramuka, pembimbing kegiatan karya ilmiah remaja, dan guru piket. Istilah tatap muka berlaku untuk pelaksanaan beban kerja guru yang terkait dengan pelaksanaan pembelajaran. Beban kerja guru untuk melaksanakan pembelajaran paling sedikit 24 (dua puluh empat) jam tatap muka dan paling banyak 40 (empat puluh) jam tatap muka dalam 1 (satu) minggu tersebut merupakan bagian jam kerja dari jam kerja sebagai pegawai yang secara keseluruhan paling sedikit 37,5 (tiga puluh tujuh koma lima) jam kerja dalam 1 (satu) minggu. ${ }^{5}$ PP No. 53 Tahun 2010 menyatakan bahwa: "Setiap PNS wajib masuk kerja dan menaati ketentuan jam kerja"6 Penjelasan Peraturan Pemerintah Nomor 53 Tahun 2010 pasal 3 (11) sebagai berikut:

Yang dimaksud dengan kewajiban untuk "masuk kerja dan menaati ketentuan jam kerja" adalah setiap PNS wajib datang, melaksanakan tugas, dan pulang sesuai ketentuan jam kerja serta tidak berada di tempat umum bukan karena dinas. Apabila berhalangan hadir wajib memberitahukan kepada pejabat yang berwenang. Keterlambatan masuk kerja dan/atau pulang cepat dihitung secara kumulatif dan dikonversi $7 \frac{1}{2}$ (tujuh setengah) jam sama dengan 1 (satu) hari tidak masuk kerja. ${ }^{7}$

Peraturan Bupati Pemalang No 26 tahun 2012 tentang Hari dan Jam Kerja PNS Pemerintah Kabupaten Pemalang pasal 4 (2) mengatur jam kerja guru sebagai PNS sebagai berikut : Hari Senin - Kamis pukul 07.00 WIB - pukul 14.00 WIB, hari Jum'at pukul 07.00 WIB - pukul

\footnotetext{
${ }^{4}$ Ibid, pasal 52 ayat (1)

${ }^{5}$ Penjelasan Peraturan Pemerintah Nomor 74 Tahun 2008 tentang Guru pasal 52 ayat $(1-2)$

${ }^{6}$ PP 53 Tahun 2010 tentang Disiplin PNS, Pasal 3 ( 11)

7 Penjelasan PP 53 Tahun 2010 tentang Disiplin PNS, Pasal 3 ( 11)
} 
11.00 WIB, dan hari Sabtu pukul 07.00 - pukul 12.30 WIB. ${ }^{8}$ Semua PNS termasuk Guru SD PNS wajib mentaati jam kerja yang telah diatur dalam Peraturan Bupati Pemalang Nomor 26 tahun 2012 tentang Hari dan jam Kerja PNS Pemerintah Kabupaten Pemalang, yang merupakan penjabaran dari Peraturan Pemerintah Nomor 53 tahun 2010 tentang Disiplin PNS dan Permendiknas Nomor 74 tahun 2008 tentang Guru, tetapi pada tataran pelaksanaan terasa kurang pas bagi Guru SD. Sebab waktu pelaksanaan mengajar memang dilaksanakan sesuai jadwal pelajaran sehingga waktunya tetap setiap hari. Tugas Guru SD selain mengajar juga harus melaksanakan tugas tambahan seperti pembina pramuka, pembimbing kegiatan karya ilmiah remaja, memberikan pelajaran tambahan, menilai, mengalisis dan lain-lain, yang membutuhkan waktu pelaksanaan fleksibel. Pelaksanaan tugas tambahan biasanya dilaksanakan pada sore hari mulai pukul 15.00 WIB sampai dengan pukul 17.00 WIB, sehingga apabila Guru SD, melaksanakan ketentuan jam kerja sesuai Peraturan Bupati Pemalang No 26 tahun 2012, maka banyak tugas guru SD yang tidak dapat terselesaikan. Mereka harus pulang dari sekolah pukul 14.00 WIB, padahal pukul 15.00 harus kembali ke sekolah untuk melaksanakan tugas tambahan, bahkan tugas tambahan sering dilaksanakan pada malam hari, lebih parah lagi bagi Guru SD yang rumahnya jauh, mereka tidak punya waktu lagi untuk istirahat maupun keluarga, padahal guru tidak mempunyai hak cuti tahunan.

Fenomena ini terjadi pada Guru SD di UPPK Taman Dinas Pendidikan Pemuda dan Olahraga Kabupaten Pemalang, yang hampir seluruhnya adalah Pegawai Negeri Sipil. Berdasarkan pengamatan penulis dan hasil wawancara dengan Pengawas Sekolah, Kepala Sekolah, Guru, Siswa dan Komite Sekolah di UPPK Taman Dinas

8 Peraturan Bupati Pemalang No 26 tahun 2012 tentang Hari dan Jam Kerja PNS Pemerintah Kabupaten Pemalang, Pasal 4 (2) 
Pendidikan Pemuda dan Olahraga Kabupaten Pemalang, terjadi pelanggaran disiplin Guru SD dalam mentaati peraturan perundangundangan tentang disiplin PNS yakni dalam mentaati jam kerja PNS dan pelanggaran dalam melaksanakan tugas utamanya.

Berkaitan dengan paparan di atas, maka penulis bermaksud mengkaji dan membahas pada penelitian ini secara yuridis tentang: Implementasi Disiplin Guru SD Dalam Mentaati Peraturan Perundang Undangan Tentang Disiplin PNS Di UPPK Taman Dinas Pendidikan Pemuda dan Olahraga Kabupaten Pemalang.

\section{B. METODE PENELITIAN}

Berdasarkan tujuan penelitian di atas, metode pendekatan pada penelitian ini adalah metode pendekatan yuridis sosiologis, dengan pertimbangan permasalahan yang diteliti adalah mengenai hubungan aspek sosial pendidikan terhadap faktor yuridis. ${ }^{9}$ Pendekatan yuridis sosiologis merupakan suatu pendekatan penelitian terhadap efektifitas hukum, maka relevansinya hukum tidak dikonsesikan sebagai suatu gejala normatif yang otonom, tetapi suatu institusi sosial yang secara riil berkaitan dengan variabel-variabel sosial. Secara eksplisit dapat diperjelas bahwa metode pendekatan sosiologis merupakan penelitian yang melihat dan menganalisis tentang bekerjanya hukum dalam tataran kenyataan. ${ }^{10}$

\section{HASIL PENELITIAN DAN PEMBAHASAN}

1. Implementasi Disiplin Guru SD Dalam Mentaati Peraturan Perundang-Undangan Tentang Disiplin PNS Di UPPK Taman

\footnotetext{
${ }^{9}$ Lexy J. Moleong. 2000. Metodologi Penelitian Hukum. Citra Aditya Bakti. Bandung. h. 11.

${ }^{10}$ Soerjono Soekanto, 1984, Pengantar Penelitian Hukum, Universitas Indonesia Pers, Jakarta, h. 51.
} 
Implementasi disiplin guru SD dalam mentaati peraturan perundang-undangan tentang disiplin PNS di UPPK Taman Dindikpora Kabupaten Pemalang didasarkan pada Peraturan Pemerintah Nomor 53 tahun 2010 tentang Disiplin Pegawai Negeri Sipil, Peraturan Kepala BKN Nomor 21 tahun 2010 tentang Ketentuan Pelaksanaan Peraturan Pemerintah Nomor 53 tahun 2010 tentang Disiplin Pegawai Negeri Sipil, dan Peraturan Bupati Pemalang No 26 tahun 2012 tentang Hari dan Jam Kerja PNS Pemerintah Kabupaten Pemalang.

Dalam PP 53 tahun 2010 disebutkan bahwa: Setiap PNS wajib datang, melaksanakan tugas, dan pulang sesuai ketentuan jam kerja serta tidak berada ditempat umum bukan karena dinas. Apabila berhalangan hadir wajib memberitahukan kepada pejabat yang berwenang. Keterlambatan masuk kerja dan atau pulang cepat dihitung secara komulatuf dan dikonversi $7 \quad \frac{1}{2} 2$ (tujuh setengah) jam sama dengan 1 (satu) hari tidak masuk kerja. ${ }^{11}$ Beban kerja guru untuk melaksanakan pembelajaran paling sedikit 24 (dua puluh empat) jam tatap muka dan paling banyak 40 (empat puluh) jam tatap muka dalam 1 (satu) minggu tersebut merupakan bagian jam kerja dari jam kerja sebagai pegawai yang secara keseluruhan paling sedikit 37,5 (tiga puluh tujuh koma lima) jam kerja dalam 1 (satu) minggu ${ }^{12}$ Keputusan Bupati Pemalang No 26 tahun 2012 tentang Hari dan Jam Kerja PNS Pemerintah Kabupaten Pemalang, menyebutkan: ${ }^{13}$

Pasal 3:

${ }^{11}$ PP No. 53 Tahun 2010 tentang Disiplin Pegawai Negeri Sipil Pasal 3 (11)

12 Penjelasan PP 74 Tahun 2008 tentang Guru Pasal 52 ayat (2)

13 Peraturan Bupati Pemalang No 26 tahun 2012 tentang Hari dan Jam Kerja PNS Pemerintah Kabupaten Pemalang Pasal 3 (1-2) dan Pasal 4 (1-2) 
(1) Hari kerja PNS pada satuan kerja atau unit kerja Pemerintah Kabupaten Pemalang ditetapkan 5 (lima) hari kerja mulai hari Senin sampai dengan Jum'at.

(2) Jam kerja efektif dalam 1 (satu) minggu sebagaimana dimaksud pada ayat (1) ditetapkan sebagai berikut:

a. Hari Senin sampai dengan kamis pukul 07.30 sampai dengan pukul 16.00 WIB;

b. Hari Jum'at pukul 07.30 sampai dengan pukul 11.00 WIB Pasal 4:

(1) Dikecualikan dari ketentuan tentang hari dan jam kerja sebagaimana dimaksud dalam pasal 3 adalah:

a. Rumah Sakit Umum Daerah, Pusat Kesehatan Masyarakat;

b. Lembaga Pendiditetapkan TK, SD, SLTP, dan SLTA

(2) Hari dan jam kerja efektif dalam 1 (satu) minggu sebagaimana dimaksud pada ayat (1) ditetapkan sebagai berikut:

a. Hari Senin sampai dengan Kamis pukul 07.00 sampai dengan pukul 14.00 WIB.

b. Hari Jum'at pukul 07.00 sampai dengan pukul 11.00 WIB.

C. Hari Sabtu pukul 07.00 sampai dengan pukul 12.30 WIB.

Guru SD sebagai PNS mempunyai kewajiban yang sama dengan PNS lainnya dalam melaksanakan ketentuan jam kerja PNS yakni 37 $1 / 2$ jam dalam satu minggu. Perbedaannya hanya pada waktu pelaksanaannya yakni Guru SD bekerja selama 6 (enam) hari kerja, sedangkan PNS selain guru 5 (lima) hari kerja, tetapi dalam hitungan jumlah waktu relatif sama yakni 37 1/2 jam. Guru yang 
melanggar ketentuan jam kerja PNS akan dijatuhi hukuman disiplin berdasarkan peraturan perundang-undangan yang berlaku. Penjatuhan hukuman bagi Guru SD yang melanggar peraturan jam kerja PNS dilaksanakan berdasarkan tingkat dan jenis pelanggaran yang dilakukan. PP 53 tahun 2010 tentang disiplin PNS pasal 7 mengatur tingkat dan jenis hukuman disiplin, sebagai berikut: ${ }^{14}$

a. Tingkat hukuman disiplin terdiri dari:

1) hukuman disiplin ringan;

2) hukuman disiplin sedang; dan

3) hukuman disiplin berat.

b. Jenis hukuman disiplin ringan sebagaimana dimaksud pada ayat (1) huruf a terdiri dari:

1) teguran lisan;

2) teguran tertulis; dan

3) pernyataan tidak puas secara tertulis.

c. Jenis hukuman disiplin sedang sebagaimana dimaksud pada ayat (1) huruf $b$ terdiri dari :

1) Penundaan kenaikan gaji berkala selama 1 (satu) tahun;

2) Penundaan kenaikan pangkat selama 1 (satu) tahun; dan

3) Penurunan pangkat setingkat lebih rendah selama 1 (satu) tahun

d. Jenis hukuman disiplin berat sebagaimana dimaksud pada ayat (1) huruf $\mathrm{c}$ terdiri dari:

1) Penurunan pangkat setingkat lebih rendah selama 3 (tiga) tahun.

2) Pemindahan dalam rangka penurunan jabatan setingkat lebih rendah.

3) Pembebasan dari jabatan; 
4) Pemberhentian dengan hormat tidak tas permintaan sendiri sebagai PNS; dan

5) Pemberhentian tidak hormat sebagai PNS.

Secara rinci hukuman disiplin bagi PNS yang melanggar ketentuan jam kerja, dapat dilihat pada tabel berikut ini:

Tabel 6

Hukuman Disiplin Bagi PNS

Yang Melanggar Ketentuan Jam Kerja

\begin{tabular}{|l|l|l|l|}
\hline No & Tidak Masuk & $\begin{array}{c}\text { Tingkat } \\
\text { Hukuma } \\
\mathrm{n}\end{array}$ & \multicolumn{1}{|c|}{ Jenis Hukuman } \\
\hline 1 & 5 Hari Kerja & Ringan & Teguran lisan \\
\hline 2 & $6-10$ Hari Kerja & Ringan & Teguran tertulis \\
\hline 3 & $\begin{array}{l}11-15 \text { Hari } \\
\text { Kerja }\end{array}$ & Ringan & Pernyataan tidak puas secara tertulis \\
\hline 4 & $\begin{array}{l}16-20 \text { Hari } \\
\text { Kerja }\end{array}$ & $\begin{array}{l}\text { Sedan } \\
\text { g }\end{array}$ & $\begin{array}{l}\text { Penundaan kenaikan gaji berkala } \\
\text { selama 1 (satu) tahun }\end{array}$ \\
\hline 5 & $\begin{array}{l}21-25 \text { Hari } \\
\text { Kerja }\end{array}$ & $\begin{array}{l}\text { Sedan } \\
\text { g }\end{array}$ & $\begin{array}{l}\text { Penundaan kenaikan pangkat selama } \\
1 \text { (satu) tahun }\end{array}$ \\
\hline 6 & Kerja & Sedan & $\begin{array}{l}\text { Penurunan pangkat setingkat lebih } \\
\text { rendah selama 1 (satu) tahun }\end{array}$ \\
\hline 7 & $\begin{array}{l}31-35 \text { Hari } \\
\text { Kerja }\end{array}$ & Berat & $\begin{array}{l}\text { Penurunan pangkat setingkat lebih } \\
\text { rendah selama 3 (tiga) tahun }\end{array}$ \\
\hline 8 & $\begin{array}{l}36-40 \text { Hari } \\
\text { Kerja }\end{array}$ & Berat & $\begin{array}{l}\text { Pemindahan dalam rangka penurunan } \\
\text { jabatan setingkat lebih rendah }\end{array}$ \\
\hline 9 & $\begin{array}{l}41-45 \text { Hari } \\
\text { Kerja }\end{array}$ & Berat & $\begin{array}{l}\text { Pembebasan dari jabatan bagi PNS } \\
\text { yang menduduki jabatan struktural }\end{array}$ \\
\hline
\end{tabular}




\begin{tabular}{|l|l|l|l|}
\hline 10 & & & atau fungsional tertentu \\
\hline & & $\begin{array}{l}\text { Pemberhentian dengan hormat tidak } \\
\text { atas perrmintaan sendiri atau } \\
\text { pemberhentian tidak dengan hormat } \\
\text { sebagai PNS }\end{array}$ \\
\hline
\end{tabular}

\section{Problematika Implementasi Disiplin Guru SD Dalam} Mentaati Peraturan Perundang-Undangan Tentang Disiplin PNS Di UPPK Taman

Implementasi Peraturan Pemerintah Nomor 53 Tahun 2010 Tentang Disiplin Pegawai Negeri Sipil yang diatur lebih rinci dalam Peraturan Bupati Pemalang Nomor 26 Tahun 2012 tentang Hari dan Jam Kerja PNS Pemerintah Kabupaten Pemalang, belum dapat dilaksanakan oleh semua guru SD di UPPK Taman Dindikpora Kabupaten Pemalang.

Problema implementasi Peraturan disiplin PNS dalam mentaati jam kerja, diawali dengan kontradiksi peraturan tersebut dengan beban kerja guru, yang pelaksanaannya membutuhkan waktu yang fleksibel. Guru SD wajib melaksanakan peraturan disiplin PNS dalam mentaati jam kerja PNS yaitu dalam satu minggu adalah 37 1/2 jam, dengan rincian masuk pukul 07.00 WIB dan pulang pukul 14.00 WIB pada hari Senin sampai Kamis, Hari jum"at pulang pukul 11.00 dan hari sabtu pulang pukul 12.30. Di sisi lain Guru SD harus melaksanakan aktifitas dalam rangka melaksanakan beban kerja guru yang membutuhkan waktu pelaksanaan fleksibel atau tidak semua beban kerja guru dapat dilaksanakan pada kisaran waktu jam kerja guru sesuai dengan Peraturan Bupati Pemalang Nomor 26 Tahun 2012. Padahal pelaksanaan beban kerja guru yang dilaksanakan di luar jam kerja, tidak dihitung sebagai pelaksanaan jam kerja. 
Berdasarkan hasil wawancara dari para narasumber, bahwa problematika yang muncul dari implementasi disiplin Guru SD dalam mentaati peraturan perundang-undangan tentang disiplin PNS di UPPK Taman Dinas Pendidikan Pemuda dan Olah Raga Kabupaten Pemalang adalah belum semua guru SD mentaati peraturan disiplin PNS tentang jam kerja PNS, yang penyebabnya adalah:

a. Intern

1) Guru belum memahami tentang peraturan disiplin PNS.

2) Guru belum menyadari pentingnya mentaati disiplin, tidak disiplinya guru akan mengakibatkan tidak tercapainya tujuan pembelajaran.

3) Guru belum mengindahkan peraturan disiplin PNS tentang jam kerja PNS, karena pelaksanaan pengawasan belum maksimal.

4) Guru belum berniat mentaati peraturan disiplin PNS, karena belum diterapkan sangsi yang tegas bagi yang melanggar peraturan itu.

b. Ekstern

1) Belum dilaksanakan sosialisasi secara khusus pada Guru SD tentang PP No. 53 Tahun 2010 Tentang Disiplin Pegawai Negeri Sipil dan Peraturan Bupati Pemalang Nomor 26 Tahun 2012 tentang Hari dan Jam Kerja PNS Pemerintah Kabupaten Pemalang.

2) Belum intensif pelaksanaan pengawasan implementasi disiplin Guru SD dalam mentaati peraturan disiplin PNS tentang jam kerja PNS.

3) Belum diterapkan sangsi yang tegas, bagi Guru SD yang melanggar peraturan disiplin PNS dalam mentaati jam kerja PNS 
4) Belum dilaksanakan pengaturan ulang tentang waktu pelaksanaan tugas guru sehingga semua tugas guru dapat dilaksanakan pada jam kerja guru yakni: dari pukul 07.00 WIB

- 14.00 WIB pada hari Senin sampai Kamis, pukul 07.00 WIB - 11.00 WIB pada hari Jum'at dan pukul 07.00 WIB - 12.30 WIB pada hari Sabtu.

\section{Solusi Implementasi Disiplin Guru SD Dalam Mentaati} Peraturan Perundang-Undangan Tentang Disiplin PNS Di UPPK Taman

Problem yang muncul ketika Implementasi Peraturan Pemerintah Nomor 53 Tahun 2010 Tentang Disiplin Pegawai Negeri Sipil dan Peraturan Bupati Pemalang Nomor 26 Tahun 2012 tentang Hari dan Jam Kerja PNS Pemerintah Kabupaten Pemalang adalah belum semua guru SD mentaati peraturan disiplin PNS tentang jam kerja PNS.

Berdasarkan hasil wawancara dari para narasumber, bahwa solusi untuk mengatasi problematika yang mengakibatkan implementasi disiplin Guru SD dalam mentaati peratuan perundangundangan tentang disiplin PNS khususnya kedisiplinan dalam mentaati jam kerja belum terlaksana dengan baik adalah sebagai berikut:

a. Perlu dilaksanakan sosialisasi pada Guru SD tentang Peraturan Pemerintah Nomor 53 Tahun 2010 Tentang Disiplin Pegawai Negeri Sipil dan Peraturan Bupati Pemalang Nomor 26 Tahun 2012 tentang Hari dan Jam Kerja PNS Pemerintah Kabupaten Pemalang.

b. Pelaksanaan pengawasan terhadap keterlaksanaan implementasi disiplin Guru SD dalam mentaati peraturan jam kerja PNS lebih diintensifkan. 
c. Pemberian sangsi yang tegas kepada Guru SD yang melanggar peraturan disiplin PNS dalam mentaati jam kerja PNS harus dilaksanakan secara maksimal.

d. Perlu adanya pengaturan ulang tentang waktu pelaksanaan tugas guru sehingga semua tugas guru dapat dilaksanakan pada jam kerja tanpa melanggar peraturan disiplin PNS tentang jam kerja PNS.

\section{PENUTUP}

\section{Kesimpulan}

Berdasarkan pemaparan data dan pembahasan, maka penulis dapat memberikan kesimpulan sebagai berikut:

a. Implementasi disiplin Guru SD dalam mentaati peraturan perundang - undangan tentang disiplin PNS di UPPK Taman Dinas Pendidikan Pemuda dan Olah Raga Kabupaten Pemalang, yakni pelaksanaan Peraturan Pemerintah Nomor 53 Tahun 2010 tentang Disiplin PNS, yang mengatur tentang kewajiban PNS untuk datang, melaksanakan tugas, dan pulang sesuai ketentuan jam kerja serta tidak berada di tempat umum bukan karena dinas, serta apabila berhalangan hadir wajib memberitahukan kepada pejabat yang berwenang; dan Peraturan Bupati Pemalang Nomor 26 Tahun 2012 tentang Hari dan Jam Kerja PNS Pemerintah Kabupaten Pemalang, yang mengatur jam kerja guru, yakni:

1) Hari Senin - Kamis dari pukul 07.00 WIB sampai pukul 14.00 WIB.

2) Hari Jum'at dari pukul 07.00 WIB sampai pukul 11.00 WIB

3) Hari Sabtu pukul 07.00 WIB sampai pukul 12.30 WIB 
b. Problematika yang muncul dari implementasi disiplin Guru SD dalam mentaati peraturan perundang-undangan tentang disiplin PNS di UPPK Taman Dinas Pendidikan Pemuda dan Olah Raga Kabupaten Pemalang adalah belum semua guru SD di UPPK Taman Dinas Pendidikan Pemuda dan Olahraga Kabupaten Pemalang mentaati peraturan disiplin PNS tentang jam kerja PNS, yang penyebabnya adalah:

1) Intern

a) Guru belum memahami tentang peraturan disiplin PNS tentang jam kerja PNS.

b) Guru belum menyadari pentingnya mentaati disiplin, karena ketidakdisiplinan guru berakibat pada tidak tercapainya tujuan pembelajaran.

c) Guru belum mengindahkan peraturan disiplin PNS tentang jam kerja PNS, karena pengawasan implementasi peraturan disiplin PNS tentang jam kerja PNS belum maksimal.

d) Guru belum berniat mentaati peraturan disiplin PNS, karena belum diterapkan sangsi yang tegas bagi yang melanggar peraturan itu.

2) Ekstern

a) Belum dilaksanakan sosialisasi secara khusus pada Guru SD tentang PP No. 53 Tahun 2010 Tentang Disiplin Pegawai Negeri Sipil dan Peraturan Bupati Pemalang Nomor 26 Tahun 2012 tentang Hari dan Jam Kerja PNS Pemerintah Kabupaten Pemalang.

b) Belum intensif pelaksanaan pengawasan terhadap implementasi disiplin Guru SD dalam mentaati peraturan disiplin PNS tentang jam kerja PNS. 
c) Belum diterapkan sangsi yang tegas, bagi Guru SD yang melanggar peraturan disiplin PNS dalam mentaati jam kerja PNS

d) Belum dilaksanakan pengaturan ulang tentang waktu pelaksanaan tugas guru sehingga semua tugas guru dapat dilaksanakan pada jam kerja yakni: dari pukul 07.00 WIB 14.00 WIB pada hari Senin sampai Kamis, pukul 07.00 WIB - 11.00 WIB pada hari Jum'at dan pukul 07.00 WIB 12.30 WIB pada hari Sabtu.

c. Solusi untuk mengatasi problematika yang muncul dari implementasi disiplin Guru SD dalam mentaati peraturan periundang-undangan tentang disiplin PNS di UPPK Taman Dinas Pendidikan Pemuda dan Olah Raga Kabupaten Pemalang antara lain:

1) Perlu dilaksanakan sosialisasi pada Guru SD tentang Peraturan Pemerintah Nomor 53 Tahun 2010 Tentang Disiplin Pegawai Negeri Sipil dan Peraturan Bupati Pemalang Nomor 26 Tahun 2012 tentang Hari dan Jam Kerja PNS Pemerintah Kabupaten Pemalang.

2) Pelaksanaan pengawasan terhadap keterlaksanaan implementasi disiplin Guru SD dalam mentaati peraturan jam kerja PNS lebih diintensifkan.

3) Pemberian sangsi yang tegas kepada Guru SD yang melanggar peraturan disiplin PNS dalam mentaati jam kerja PNS harus dilaksanakan secara maksimal.

4) Perlu adanya pengaturan ulang tentang waktu pelaksanaan tugas guru sehingga semua tugas guru dapat dilaksanakan pada jam kerja yakni: dari pukul 07.00 WIB - 14.00 WIB pada hari Senin sampai Kamis, pukul $07.00-11.00$ WIB pada hari 
Jum'at dan pukul 07.00 WIB - 12.30 WIB pada hari Sabtu, sehingga guru dapat melaksanakan semua tugas tanpa melanggar peraturan disiplin PNS tentang jam kerja PNS.

\section{Saran}

Berdasarkan kesimpulan di atas, maka penulis dapat memberikan saran sebagai berikut:

a. Pemerintah Kabupaten Pemalang dalam hal ini Badan Kepegawaian Daerah (BKD) atau Dinas pendidikan Pemuda dan Olahraga perlu melaksanakan sosialisasi pada Guru SD tentang Peraturan Pemerintah Nomor 53 Tahun 2010 Tentang Disiplin Pegawai Negeri Sipil dan Peraturan Bupati Pemalang Nomor 26 Tahun 2012 tentang Hari dan Jam Kerja PNS Pemerintah Kabupaten Pemalang

b. Pengawas Sekolah untuk lebih intensif dalam melaksanakan pembinaan dan pengawasan terhadap Guru SD dalam mentaati peraturan disiplin PNS tentang jam kerja PNS.

c. Pejabat yang mendapat tugas memberikan sangsi terhadap PNS yang melanggar disiplin, menerapkan sangsi tegas bagi PNS yang melakukan pelanggaran disiplin.

d. Kepala Sekolah perlu melakukan pengaturan ulang tentang waktu pelaksanaan tugas guru sehingga semua tugas guru dapat dilaksanakan pada jam kerja yakni: dari pukul 07.00 WIB - 14.00 WIB pada hari Senin sampai Kamis, pukul 07.00 - 11.00 WIB pada hari Jum'at dan pukul 07.00 WIB - 12.30 WIB pada hari Sabtu, sehingga guru dapat melaksanakan semua tugas tanpa melanggar peraturan disiplin PNS tentang jam kerja PNS. 


\section{DAFTAR PUSTAKA}

\section{A. Buku}

A.S. Moenir,1983, Pendekatan Manusia dan Organisasi Terhadap Pembinaan Kepegawaian, Gunung Agung, Jakarta

Bubb, S., \& Earley, P, 2004, Managing teacher workload, Paul Chapman Publishing, London

Byars L \& Rue LW, 1991, Management (skills and application), Irwin McGraw Hill, Boston

Dean, Joan. 1991, Professional Development in School, Ohio University Press, Philadelphia

Dedi Supriadi, 1998, Mengangkat Citra dan Martabat Guru, Adicita Karya Nusa, Yogyakarta

Handoko, Hani T, 2001, Manajemen Personalia dan Sumber Daya Manusia, BPFE, Yogyakarta

IG Wursanto, 1988, Dasar-Dasar Manajemen Personalia, Pustaka Dian Cet 2, Jakarta,

I.S. Livine, 1980, Teknik Memimpin Pegawai dan Pekerja. Terjemahan oleh Iral Soedjono, Cemerlang, Jakarta

Jalaluddin, 2003, Teologi Pendidikan, PT. RajaGrafindo Persada, Jakarta Jalaluddin, 2003, Teologi Pendidikan, PT. RajaGrafindo Persada, Jakarta

Jean D. Grambs dan C. Morris Mc Clare. 2005. Foundation of teaching, An Introduction to Modern Education, Mac education, South Melbourne

Latham GP \& Wexley KN, 1981, Increasing productivity through performance appraisal, Addison-Wesley Publishing Company, Michigan Styate University

Laurence D. Hazkew dan Jonathan C. Mc Lendon, 2001, This is Teaching, Addison wasley Longman Inc, New York

Lexy J. Moleong. 2000. Metodologi Penelitian Hukum. Citra Aditya Bakti. Bandung

Martin, R. E, Wood, G.H. \& Stevens. E.W, 1988, An introduction to teaching, Allyn \& Bacon Inc, Boston

Moch.Faizal Salam, 2003, Penyelesaian Sengketa Pegawai Negeri Sipil di Indonesia Menurut Undang-Undang No.43 Tahun 1999, Mandar Maju, Bandung 
Moekijat, 1989, Manajemen Kepegawaian, Alumni, Bandung.

Moh. Mahfud, 1988, Hukum Kepegawaian Indonesia, Liberty, Yogyakarta

Mulyasa. 2007, Menjadi Guru Profesional, T Remaja Rosdakarya. Bandung

Nainggolan, 1987, Pembinaan Pegawai Negeri Sipil, PT Pertja, Jakarta

Nitisemito Alex.S., 1988, Manajemen Personalia, Ghalia Indonesia, Jakarta.

Sanafiah Faisal, 1989, Penelitian Kualitatif; Dasar - Dasar dan Aplikasi, Yayasan Asah Asih Asuh, Malang

Siagian, Sondang P, 2003, Manajemen Sumber Daya Manusia, Umi Aksara. Jakarta

Soegeng Prijodarminto, 1994, Disiplin Kiat Menuju Sukses, Pradnya Paramita, Bandung

Soejono. 1997. Sistem dan Prosedur Kerja, Bumi Aksara, Jakarta

Tulus Tu'u. 2004. Peran Disiplin pada Perilaku dan Prestasi Siswa, PT.Gramedia Widia Sarana Indonesia, Jakarta.

Victor M. Situmorang dan Jusuf Juhir, 1994, Aspek Hukum Pengawasan Melekat di Lingkungan Aparatur Pemerintah, PT. Rineka Cipta, Jakarta

\section{B. Perundang - Undangan}

Undang - Undang Republik Indonesia Nomor 20 Tahun 2003 tentang Sistem Pendidikan Nasional

Peraturan Pemerintah Republik Indonesia Nomor 53 Tahun 2010 tentang Disiplin Pegawai Negeri Sipil

Peraturan Pemerintah Republik Indonesia Nomor 74 tahun 2008 tentang Guru dan. Dosen

Peraturan Menteri pendidikan Nasional Nomor 39 Tahun 2009 tentang Beban Kerja Guru dan Pengawas Sekolah.

Peraturan Bupati Pemalang Nomor 26 tahun 2012 tentang Hari dan Jam Kerja PNS Pemerintah Kabupaten Pemalang. 